\title{
Saudi anti-human cancer plants database (SACPD): A collection of plants with anti-human cancer activities
}

\author{
Ateeq Ahmed Al-Zahrani \\ Biology and Chemistry Department, University College at Al-Qunfudhah, Umm AL-Qura University, Makkah, Saudi Arabia
}

\begin{abstract}
Several anticancer drugs have been developed from natural products such as plants. Successful experiments in inhibiting the growth of human cancer cell lines using Saudi plants were published over the last three decades. Up to date, there is no Saudi anticancer plants database as a comprehensive source for the interesting data generated from these experiments. Therefore, there was a need for creating a database to collect, organize, search and retrieve such data. As a result, the current paper describes the generation of the Saudi anti-human cancer plants database (SACPD). The database contains most of the reported information about the naturally growing Saudi anticancer plants. SACPD comprises the scientific and local names of 91 plant species that grow naturally in Saudi Arabia. These species belong to 38 different taxonomic families. In Addition, 18 species that represent 16 family of medicinal plants and are intensively sold in the local markets in Saudi Arabia were added to the database. The website provides interesting details, including plant part containing the anticancer bioactive compounds, plants locations and cancer/cell type against which they exhibit their anticancer activity. Our survey revealed that breast, liver and leukemia were the most studied cancer cell lines in Saudi Arabia with percentages of $27 \%, 19 \%$ and $15 \%$, respectively. The current SACPD represents a nucleus around which more development efforts can expand to accommodate all future submissions about new Saudi plant species with anticancer activities. SACPD will provide an excellent starting point for researchers and pharmaceutical companies who are interested in developing new anticancer drugs. $\mathrm{SACPD}$ is available online at https://teeqranil.wixsite.com/sapd
\end{abstract}

\section{Introduction}

Cancer is one of the main causes of morbidity and mortality in

Correspondence: Ateeq Ahmed Al-Zahrani, Biology and Chemistry Department, University College at Al-Qunfudhah, Umm AL-Qura University, Makkah, Saudi Arabia.

E-mail: aaalzahrani@uqu.edu.sa

Key words: Anticancer drugs; plants: natural medicine; database.

Received for publication: 26 December 2017.

Accepted for publication: 1 March 2018.

This work is licensed under a Creative Commons Attribution NonCommercial 4.0 License (CC BY-NC 4.0).

(C) Copyright A. Ahmed Al-Zahrani, 2018

Licensee PAGEPress, Italy

Oncology Reviews 2018; 12:349

doi:10.4081/oncol.2018.349 both, developed and developing countries. About 8.8 million deaths were reported in 2015 worldwide (World Health Organization). In Saudi Arabia, 15653-cancer incident cases were reported to the Saudi Cancer Registry (SCR) between January 01 and December 31,2013 . A total of 7,359 males (47.0\%) and 8,294 females $(53.0 \%)$ were affected by cancer. Breast cancer was the most common cancer among females whereas colorectal cancer was the most common in males. These figures are frightening and reflect the immediate need for intensive research in order to reduce cancer cases and find effective treatments. As a result, many research institution and funding agencies have been investing heavily in searching for annotative and creative strategies for fighting such serious disease.

A variety of approaches for inhibition the uncontrolled division of cancerous cells has been tested. Examples include surgery, radiation therapy, chemotherapy and immunotherapy. Recently, utilization of plant extracts has been emerged as a promising tool for controlling cancerous cell division. World Health Organization reported that about $80 \%$ of Asians and Africans consume plant products as traditional medicines. The products derived from more than 3000 plant species have been used against cancer. ${ }^{1}$ Information about these plant species can be found at Dr. Duke's Phytochemical and Ethnobotanical Databases (https://phytochem.nal.usda.gov/phytochem/search).

Compared to synthetic anticancer compounds, plant-derived anticancer compounds are considered natural, safer and have less unexpected side effects. As a result, screening plants for new and effective anticancer compounds have attracted many researchers and funding agencies worldwide. The anticancer active compounds in plants are continuously reviewed. ${ }^{2-5}$ Various plant species showed their promising and effective role in cancer treatment. Examples include; extracts from Podophyllum peltatum against lung and testicular cancer, ${ }^{6}$ compounds isolated from Curcuma longa against cancer growth in several organs such as skin and colon, ${ }^{7}$ betulin and betulinic acid from Ziziphus nummularia, ${ }^{8}$ andrographolide compound from Andrographis paniculata against several kinds of cancer including leukemia, breast and colon. ${ }^{9}$ More recently, additional lists of anticancer medicinal plant species have been reported. Examples include Cephalotaxus harringtonia, ${ }^{10}$ Euphorbia peplus, ${ }^{11}$ Phyllanthus emblica, ${ }^{12}$ Euphorbia hirta,${ }^{13}$ Aristolochia bracteolata, ${ }^{14}$ Cichorium intybus ${ }^{15}$ and Euphorbia condylocarpa. ${ }^{16}$ Interestingly, it has been reported that the combined application of plant-derived anticancer compounds and synthetic anticancer drugs can significantly improve the efficacy of chemotherapy. ${ }^{17}$

In Saudi Arabia, a large number of reports about the anticancer activities of many various extracts of different plants from different taxonomic groups has been published in national and international journals. Unfortunately such data are scattered and may be hard to find either because the absence of a recent and a comprehensive review of the subject or due to the nature of the journals in which the data were published. As a result, the use of such important data for more beneficial downstream applications has been limited. Therefore, the aim of this study was to build a database for Saudi 
anti-human cancer plants. The database provides important information about the number of the most studied anticancer plants and the type of human cancer cell lines that showed growth inhibited in response to these plants. Up to our knowledge, the SACPD database is the first database that covers details about Saudi anti-human cancer plants. The Saudi Herbal Plant Information System (SHPIS) is the only online database that gives a description of several herbal plants found in Saudi Arabia. These herbal plants used traditionally as a cure for many diseases excluding cancer.

\section{Research methods}

A systematic review was performed using Google Scholar web search engine. Keywords used for this search were 'Saudi', 'medicinal plants', 'cancer', 'cytotoxicity'. 100 pages and 2360 results were reviewed. The Google Scholar search engine was selected for its ability to search the full text of articles. The other search engines such as PubMed and Web of Science are limited to abstract searching. Species and family name's spelling were checked using http://www.ipni.org website.

The database was designed and created by the author. The website is hosted by Wix.com, a cloud-based web development platform.

\section{Results and Discussion}

\section{Database architecture and implementation}

The home page of the database provides a list of Saudi anticancer plants. The list contains the basic information such as plant's scientific and local name, plant's part, location, cell line type and references. Each reference was uploaded as a pdf file attached to the list. Users can search for a specific plant's name using the search box. The plants were alphabetically indexed based on species names. Another list of traditional medicinal plants that are commonly sold in the local markets in Saudi Arabia was created into a separate page. This list contains the basic information about medicinal plants, which are available commercially, and has its possible anticancer activities. The SACPD database allows users to add new submissions of new Saudi anticancer plants using an online submission box or by a direct electronic mail contact. Statistics of some extracted information of the search were also provided.

\section{Analysis of SACPD data}

The database consists of two lists of anticancer plants. The first list provides users with information about Saudi anti-human cancer plants that grow naturally in Saudi Arabia. The second list provides information about traditional medicinal plants with potential anticancer activities. Traditionally, these medicinal plants have been used for decades as a treatment of several diseases, including cancer and can be found in the Saudi local markets.

\section{Anticancer plants found naturally in Saudi Arabia}

In the first list, data revealed that 91 species belonging to 38 families (Figure 1) of Saudi plants showed significant anticancer activities against human cell lines. Figure 1 shows that Asteraceae, Apocynaceae, Fabaceae, Boraginaceae and Brassicaceae were the most studied Saudi anticancer plant families with percentages of 25, $10,7,3$ and 3 respectively. Rhazya stricta was reported four times as a Saudi anti-human cancer plant. ${ }^{18-21}$ More details regarding Rhazya stricta can be found in the SACPD database. Internationally, Rhazya stricta from different countries showed an inhibition effect against human cancer cells. Several studies described anticancer activities of Rhazya stricta. ${ }^{22,23}$ A review prepared by ${ }^{24}$ presents more information about the medicinal importance of Rhazya stricta. Table 125-47 shows the plant species which were studied by two or more researchers. Achillea fragrantissima and Artemisia sieberi were reported three times, by three different articles for their anticancer effect. Caralluma quadrangular, Citrullus colocynthis, Haplophyllum tuberculatum, Lactuca serriola, Pulicaria crispa, Rosa damascena trigintipetala, Rumex vesicarius, Santolina chamaecyparissus, Solanum glabratum, Verbesina encelioides were reported twice by two different articles for each plant (All references are available on the database).

Breast cancer was the most studied cancer cell lines among others with a percentage of $27 \%$. This was not surprising as breast cancer is the most common cancer among females as mentioned previously. Similarly, breast cancer is considered as the most common cancer in women worldwide, according to World Cancer Research Fund International. Figure 2 shows the percentages of all cancer cell lines indicated in the SACPD database.

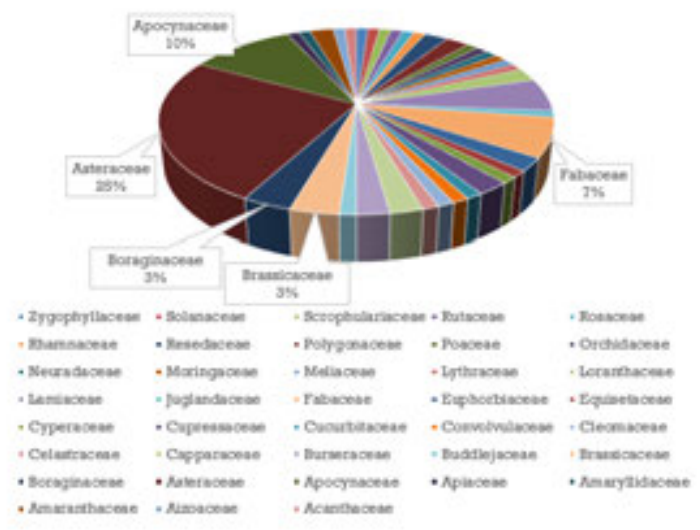

Figure 1. A pie chart of Saudi anticancer plant families as indicated in the SACPD database.

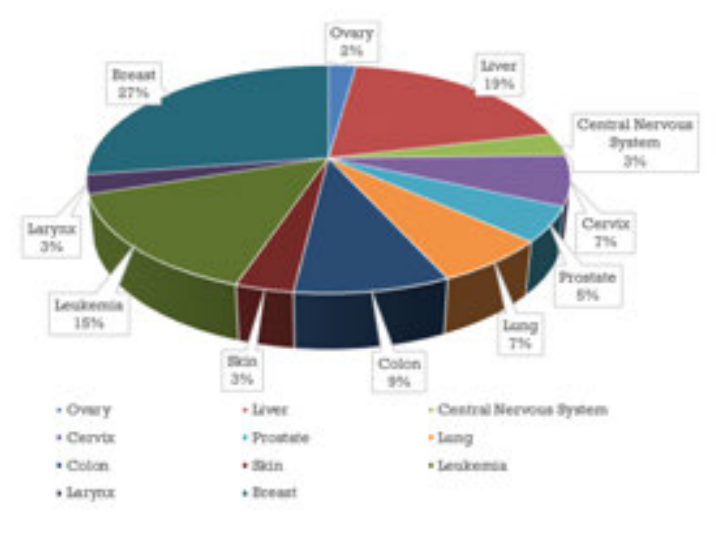

Figure 2. A pie chart of the most studied cancer cell lines as appeared in the SACPD database. 


\section{Anticancer plants sold in markets in Saudi Arabia}

In the second list, data showed that 18 species of 16 families were investigated for their possible anticancer activities. The plant families of Apiaceae and Moringaceae were the most studied ones. Among all the species (Table 2), ${ }^{48-60}$ Nigella sativa was reported five times for its ability to inhibit five cancer cell lines, mostly breast (MCF7). Several in vitro and in vivo studies were conducted on Nigella sativa and reported its medical importance as an anticancer agent. A review by ${ }^{25}$ investigated experimental results related to the capability of $N$. sativa in inhibition of cancer. The medical significance of this plant is derived from its intensive use in traditional medicine, which may be rooted back to the prophetic medicine (Ibn Maajah 3457; Shaykh Al-Albaani). Chemical anal- ysis of different organs of the plants revealed the presence of many biologically active compounds such as anthranoids, hydroxyanthracene glycosides. Similarly, Nigella sativa also contains compounds of anticancer activities against most kinds of cancer. ${ }^{26}$ It contains the thymoquinone (a strong antioxidant) and its derivatives such as thymohydroquinone, dithymoquinone, and thymol, ${ }^{27}$ antimutagenic and anticarcinogenic. ${ }^{26,28,29}$ The seeds also contain $\alpha$-hederin, which has strong activity against tumour. ${ }^{30}$

\section{Limitations and future development}

Two limitations appeared during the preparation of this sys-

Table 1. Saudi anti-human cancer plants reported by two or more researchers.

\begin{tabular}{|c|c|c|c|}
\hline Plant & Part & Cancer/Cells & Reference \\
\hline Achillea fragrantissima & Leaves, flowers & Liver (HEPG2) & $(31)$ \\
\hline Achillea fragrantissima & Leaves & Leukemia (K562 and Jurkat) & (32) \\
\hline Achillea fragrantissima & Aerial parts & Leukemia (CCRF-CEM and HL-60) & (19) \\
\hline Artemisia sieberi & Leaves, flowers & Breast (MCF7) & $(31)$ \\
\hline Artemisia sieberi & Leaves & $\begin{array}{l}\text { Breast (MCF7) } \\
\text { Cervix (HeLa) }\end{array}$ & (33) \\
\hline Artemisia sieberi & Aerial parts & Liver (HEPG2) & (34) \\
\hline Caralluma quadrangula & Aerial parts & Breast (MCF7) & (35) \\
\hline Caralluma quadrangula & Aerial parts & Breast (MCF7) & $(36)$ \\
\hline Citrullus colocynthis & Fruit & Larynx (HEp2) & (37) \\
\hline Citrullus colocynthis & Aerial parts & Leukemia (CCRF-CEM and HL-60) & (19) \\
\hline Haplophyllum tuberculatum & Aerial parts & Leukemia (CCRF-CEM and HL-60) & (19) \\
\hline Haplophyllum tuberculatum & Not specified & Skin - Melanoma & (38) \\
\hline Lactuca serriola & Aerial parts & $\begin{array}{l}\text { Breast (MCF7) } \\
\text { Liver (HEPG2) } \\
\text { Lung (A549) }\end{array}$ & $(39)$ \\
\hline Lactuca serriola & Aerial parts & Liver (HEPG2) & (40) \\
\hline Pulicaria crispa & Shoot system & $\begin{array}{l}\text { Breast (MCF7) } \\
\text { Liver (HEPG2) }\end{array}$ & $(31)$ \\
\hline Pulicaria crispa & Aerial parts & Leukemia (CCRF-CEM and HL-60) & (19) \\
\hline Rhazya stricta & Aerial parts & Leukemia (CCRF-CEM and HL-60) & (19) \\
\hline Rhazya stricta & Not specified & Breast (MCF7 and MDA-MB-231) & (18) \\
\hline Rhazya stricta & Leaves & $\begin{array}{l}\text { Colon (CACO) } \\
\text { Liver (HEPG2) }\end{array}$ & $(41)$ \\
\hline Rhazya stricta & Stems & Stem Cell (NT2) & (21) \\
\hline Rosa damascena trigintipetala & Roses & Liver (HEPG2) & $(42)$ \\
\hline Rosa damascena trigintipetala & Roses & $\begin{array}{l}\text { Liver (HEPG2) } \\
\text { Breast (MCF7) }\end{array}$ & (43) \\
\hline Rumex vesicarius & Aerial parts & Leukemia (CCRF-CEM and HL-60) & (19) \\
\hline Rumex vesicarius & Flowers & $\begin{array}{c}\text { Breast (MCF7) } \\
\text { Lung (NCI-H460) } \\
\text { Central Nervous System (SF-268) }\end{array}$ & (44) \\
\hline Santolina chamaecyparissus & Aerial parts & Liver (HEPG2) & $(45)$ \\
\hline Santolina chamaecyparissus & Aerial parts & Liver (HEPG2) & $(40)$ \\
\hline Withania somnifera & Fruits & $\begin{array}{c}\text { Breast (MCF7) } \\
\text { Liver (HEPG2) } \\
\text { Colon (Colo20 and HCT-116) } \\
\text { Leukemia (Jurkat) }\end{array}$ & $(46)$ \\
\hline Withania somnifera & Leaves & $\begin{array}{l}\text { Breast (MCF7) } \\
\text { Liver (HEPG2) } \\
\text { Colon (HCT-116) }\end{array}$ & (47) \\
\hline
\end{tabular}


Table 2. Traditional medicinal plants sold in the local markets in Saudi Arabia and reported by two or more researchers.

\begin{tabular}{lccc} 
Plant & Part & Cancer/Cells & Reference \\
Lepidium sativum & Garden Cress & Breast (MCF7) & $(48)$ \\
Lepidium sativum & Garden Cress & Breast (MCF7) & $(49)$ \\
\hline Nigella sativa & Black Seed & Breast (MCF7) & $(50)$ \\
Nigella sativa & & Liver (HEPG2) & $(52)$ \\
\hline Nigella sativa & Black Seed & Retina (911) & $(53)$ \\
Nigella sativa & Black Seed & Cervix (Siha and C33A) & $(54)$ \\
\hline Nigella sativa & Black Seed & Lung (A549) & $(55)$ \\
Petroselinum sativum & Black Seed & Breast (MCF7) & $(56)$ \\
\hline Petroselinum sativum & Parsley & Breast (MCF7) & $(57)$ \\
Trigonella foenum graecum & Parsley & Liver (HEPG2) & $(51)$ \\
\hline Trigonella foenum graecum & Fenugreek & Breast (MCF7) Larynx (HEp2) & $(58)$ \\
Zingiber officinale & Cervix (WISH) & $(59)$ \\
\hline Zingiber officinale & Fenugreek & Breast (MCF7) & $(60)$ \\
\hline
\end{tabular}

tematic review. First, many articles related to Saudi anticancer plants were not available because of copyright issues. Second, it is expected that search engines have a limited capability of covering all the key words used or the search and some data will be missing. In order to fill these two gaps, the SACPD database provides a submission box and a direct contact for adding new or missing data. Furthermore, a regular search for Saudi anti-human cancer plants will be done to ensure that the database is updated. Despite these limitations, the total number of plant species indicated by the database was 109. It is a satisfied starting point for researchers to investigate the current list's plants or deciding to study other plants that were not mentioned in the database.

\section{Conclusions}

According to the Food and Drug Administration (FDA), there are five steps of the drug development process. First, a discovery of promising drugs by laboratory work. Second, preclinical research includes testing the cytotoxicity of these drugs on animals (in vivo) or on cell lines (in vitro). Third, clinical research in which drugs are tested on people. Fourth, FDA review for making a decision to approve the drug. Fifth, FDA Post-Market Safety Monitoring. In this study, most of the reviewed articles gave general information about the cytotoxicity of the plant extracts without identification and characterization of the active compounds behind the anticancer activity of these extracts. Testing these promising Saudi plants-derived anticancer compounds on animals and people is still the missing step noticed in most of the reviewed articles. It is the pharmaceutical companies' mission to take an action towards further studying and developing of these possible drugs. SACPD database collected all promising Saudi anticancer plants into one place. This will save time, effort and money for research centres and pharmaceutical companies who are interested in developing new drugs in the field of natural anticancer products.

\section{References}

1. Kaur R, Kapoor K, Kaur H. Plants as a source of anticancer agents. J Nat Prod Plant Resour 2011;1:119-24.

2. Richard G. Antitumor agents from higher plants. the resource potential in phytochemistry. Recent Adv Phytochem 1980;14:23-51.

3. Desai AG, Qazi GN, Ganju RK, et al. Medicinal plants and cancer chemoprevention. Curr Drug Metab 2008;9:581-91.

4. Greenwell M, Rahman PK. Medicinal plants: their use in anticancer treatment. Int J Pharm Sci Res 2015;6:4103-12.

5. Tariq A, Sadia S, Pan K, et al. A systematic review on ethnomedicines of anti-cancer plants. Phytother Res 2017;31:20264.

6. Pettit GR, Tan R, Ichihara Y, et al. Antineoplastic agents, 325. Isolation and structure of the human cancer cell growth inhibitory cyclic octapeptides phakellistatin 10 and 11 from Phakellia sp. J Nat Prod 1995;58:961-5.

7. Arbiser JL, Klauber N, Rohan R, et al. Curcumin is an in vivo inhibitor of angiogenesis. Mol Med 1998;4:376.

8. Sarek J, Kvasnica M, Urban M, et al. Correlation of cytotoxic activity of betulinines and their hydroxy analogues. Bioorgan Med Chem Lett 2005;15:4196-200.

9. Jada SR, Subur GS, Matthews C, et al. Semisynthesis and in vitro anticancer activities of andrographolide analogues. Phytochemistry 2007;68:904-12.

10. Wetzler M, Segal D. Omacetaxine as an anticancer therapeutic: what is old is new again. Curr Pharm Design 2011;17:59-64.

11. Fallen RS, Gooderham M. Ingenol mebutate: an introduction. Skin Ther Lett 2012;17:1-3.

12. Mahata S, Pandey A, Shukla S, et al. Anticancer activity of Phyllanthus emblica Linn.(Indian gooseberry): inhibition of transcription factor AP-1 and HPV gene expression in cervical cancer cells. Nutr Cancer 2013;65:88-97.

13. Sharma N, Samarakoon KW, Gyawali R, et al. Evaluation of the antioxidant, anti-inflammatory, and anticancer activities of Euphorbia hirta ethanolic extract. Molecules 2014;19:1456781.

14. Subramaniyan V, Saravanan R, Baskaran D, Ramalalingam S. In-vitro free radical scavenging and anticancer potential of 
Aristolochia indica L. against MCF-7 cell line. Int J Pharm Pharm Sci 2015;7:392-6.

15. Al-Snafi AE. Medical importance of Cichorium intybus-A review. IOSR J Pharm 2016;641-56.

16. Mohammadi S, Mahboubi A, Mohammadi M, et al. Assessing the anticancer effect of the Euphorbia condylocarpa plant on AGS gastric cancer cell line. Gene Cell Tissue 2017;4:1.

17. Fulda S, Debatin KM. Sensitization for anticancer druginduced apoptosis by the chemopreventive agent resveratrol. Oncogene 2004;23:6702.

18. Baeshen NA, Elkady AI, Abuzinadah OA, Mutwakil MH. Potential anticancer activity of the medicinal herb, Rhazya stricta, against human breast cancer. Afr J Biotechnol 2012;11:8960.

19. Kuete V, Wiench B, Alsaid MS, et al. Cytotoxicity, mode of action and antibacterial activities of selected Saudi Arabian medicinal plants. BMC Complement Altern Med 2013;13:354.

20. El-Awady MA, Awad NS, El-Tarras AE. Evaluation of the anticancer activities of pomegranate (Punica granatum) and harmal (Rhazya stricta) plants grown in Saudi arabia. Int J Curr Microbiol App Sci 2015;4:1158-67.

21. Alagrafi FS, Alawad AO, Abutaha NM, et al. In vitro induction of human embryonal carcinoma differentiation by a crude extract of Rhazya stricta. BMC Complem Alternat Med 2017; 17:342.

22. Siddiqui S, Bukhari AQS. I-leucopenic effect of Rhazya stricta. Nature 1972;235:393.

23. Mukhopadhyay S, Handy GA, Funayama S, Cordell GA. Anticancer indole alkaloids of Rhazya stricta. J Nat Prod 1981;44:696-700.

24. Marwat SK, Usman K, Shah SS, et al. A review of phytochemistry, bioactivities and ethno medicinal uses of Rhazya stricta Decsne (Apocynaceae). Afr J Microbiol Res 2012;6:1629-41.

25. Majdalawieh AF, Fayyad MW. Recent advances on the anticancer properties of Nigella sativa, a widely used food additive. J Ayurveda Integrat Med 2016;7:173-80.

26. Khan A, Chen HC, Tania M, Zhang DZ. Anticancer activities of Nigella sativa (black cumin). Afr J Trad Complem Altern Med 2011;8:5S.

27. Badary OA, Taha RA, Gamal El-Din AM, Abdel-Wahab MH. Thymoquinone is a potent superoxide anion scavenger. Drug Chem Toxicol 2003;26:87-98.

28. Bourgou S, Ksouri R, Skandrani I, et al. Antioxidant and antimutagenic activities of the essential oil and methanol extract from Tunisian Nigella sativa L. (Ranunculaceae). Ital J Food Sci 2008;20:2.

29. Khader M, Bresgen N, Eckl PM. Antimutagenic effects of ethanolic extracts from selected Palestinian medicinal plants. J Ethnopharmacol 2010;127:319-24.

30. Huat BTK, Swamy SMK. Intracellular glutathione depletion and reactive oxygen species generation are important in $\alpha$-hederin-induced apoptosis of P388 cells. Mol Cell Biochem 2003;245:127-39.

31. El-Naggar SA, Abdel-Farid IB, Elgebaly HA, Germoush MO. Metabolomic profiling, antioxidant capacity and in vitro anticancer activity of some compositae plants growing in Saudi Arabia. Afr J Pharm Pharmacol 2015;9:764-74.

32. Alenad AM, Al-Jaber NA, Krishnaswamy S, et al. Achillea fragrantissima extract exerts its anticancer effect via induction of differentiation, cell cycle arrest and apoptosis in chronic myeloid leukemia (CML) cell line K562. J Med Plants Res 2013;7:1561-7.

33. Alwahibi LH, Abdel-Mageed WM, Abdelkader MS, et al. Sesquiterpene Lactones and Flavonoids from Artemisia sieberi. IJPPR 2016;8:639-44.

34. Abutaha N, Mashaly AM, Farooq M, Wadaan MA. Apoptotic potential of Artemsia sieberia Besser (Asteraceae) fraction against human cancer cell lines. Trop J Pharm Res 2015;14:1779-85.

35. Almehdar H, Abdallah HM, Osman AM, Abdel-Sattar EA. In vitro cytotoxic screening of selected Saudi medicinal plants. J Nat Med 2012;66:406-12.

36. Abdallah HM, Osman AM, Almehdar H, Abdel-Sattar E. Acylated pregnane glycosides from Caralluma quadrangula. Phytochemistry 2013;88:54-60.

37. Latif A, Amer HM, Homad ME, et al. Medicinal plants from Saudi Arabia and Indonesia: In vitro cytotoxicity evaluation on Vero and Hep-2 cells. J Med Plants Res 2014;8:1065-73.

38. Alqathama A, Prieto JM. Anti-migratory and cytotoxic properties of medicinal plants against melanoma. Eur $\mathrm{J}$ Cancer 2014;50:S198.

39. Elsharkawy E, Alshathly M. Anticancer activity of Lactuca steriolla growing under dry desert condition of Northern Region in Saudi Arabia. J Nat Sci 2013;3:18.

40. Elsharkawy E, Aljohar H. Anticancer screening of medicinal plants growing in the Northern region of Saudi Arabia. Natl J Physiol Pharm Pharmacol 2016;6:241-6.

41. El-Awady MA, Awad NS, El-Tarras AE. Evaluation of the anticancer activities of pomegranate (Punica granatum) and harmal (Rhazya stricta) plants grown in Saudi arabia. Int J Curr Microbiol App Sci 2015;4:1158-67.

42. Abdel-Hameed E-S, Bazaid SA, Salman MS. Characterization of the phytochemical constituents of Taif rose and its antioxidant and anticancer activities. Biomed Res Int 2013;2013:345465.

43. Hagag HA, Bazaid SA, Abdel-Hameed ESS, Salman M. Cytogenetic, cytotoxic and GC-MS studies on concrete and absolute oils from Taif rose, Saudi Arabia. Cytotechnology 2014;66:913-23.

44. Gomaa SB, Saleh NM. Medicinal attributes of Rumex vesicarius (Polygonaceae) growing in Sakaka, AlJouf, Saudi Arabia. Med J Cairo Univ 2014;82:917-26.

45. El-sharkawy ER. Anticancer effect and seasonal variation in oil constituents of Santolina chamaecyparissu. Chem Mater Res 2014;6:3.

46. Abutaha N. In vitro antiproliferative activity of partially purified Withania somnifera fruit extract on different cancer cell lines. J Balkan Union Oncol 2015;20:625-30.

47. Alfaifi MY, Saleh KA, El-Boushnak MA, et al. Antiproliferative activity of the Methanolic extract of Withania somnifera leaves from Faifa Mountains, Southwest Saudi Arabia, against several human cancer cell lines. Asian Pacific J Cancer Prevent 2016;17:2723-6.

48. Mahassni SH, Al-Reemi RM. Apoptosis and necrosis of human breast cancer cells by an aqueous extract of garden cress (Lepidium sativum) seeds. Saudi J Biol Sci 2013;20:131-9.

49. Mahassni SH, Al-Reemi RM. Cytotoxic effect of an aqueous extract of Lepidium sativum L. seeds on human breast cancer cells. Indian J Trad Knowledge 2013;12:605-14.

50. Al-Oqail MM, Al-Sheddi ES, Al-Massarani SM, et al. Nigella sativa seed oil suppresses cell proliferation and induces ROS dependent mitochondrial apoptosis through p53 pathway in hepatocellular carcinoma cells. South Afr J Bot 2017;112:708.

51. Al-Oqail MM, Farshori NN, Al-Sheddi ES, et al. In vitro cytotoxic activity of seed oil of fenugreek against various cancer cell lines. Asian Pac J Cancer Prev 2013;14:1829-2.

52. Hussain KIA, Ruskam A, Hamdan S. The effects of Habbatus 
sauda (Nigella sativa) on cancer cell lines: a scientific and Islamic approach. Perintis eJournal 2012;2.

53. Ichwan SJ, Al-Ani IM, Bilal HG, et al. Apoptotic activities of thymoquinone, an active ingredient of black seed (Nigella sativa), in cervical cancer cell lines. Chin J Physiol 2014;57:24955.

54. Al-Sheddi ES, Farshori NN, Al-Oqail MM, et al. Cytotoxicity of Nigella sativa seed oil and extract against human lung cancer cell line. Asian Pac J Cancer Prev 2014;15:983-7.

55. Alhazmi MI, Hasan TN, Shafi G, et al. Roles of p53 and caspases in induction of apoptosis in MCF-7 breast cancer cells treated with a methanolic extract of Nigella sativa seeds. Asian Pac J Cancer Prev 2014;15:9655-60.

56. Farshori NN, Al-Sheddi ES, Al-Oqail MM, et al. Anticancer activity of Petroselinum sativum seed extracts on MCF-7 human breast cancer cells. Asian Pac J Cancer Prev 2013;14:5719-23.

57. Farshori NN, Al-Sheddi ES, Al-Oqail MM, et al. Cytotoxicity assessments of Portulaca oleracea and Petroselinum sativum seed extracts on human hepatocellular carcinoma cells (HepG2). Asian Pac J Cancer Prev 2014;15:6633-8.

58. Alshatwi AA, Shafi G, Hasan TN, et al. Fenugreek induced apoptosis in breast cancer MCF-7 cells mediated independently by fas receptor change. Asian Pac J Cancer Prev 2013;14:5783-8.

59. Elkady AI, Abuzinadah OA, Baeshen NA, Rahmy TR. Differential control of growth, apoptotic activity, and gene expression in human breast cancer cells by extracts derived from medicinal herbs Zingiber officinale. J Biomed Biotechnol 2012;2012:614356.

60. Elkady AI, Hussein RA, Abu-Zinadah OA. Differential control of growth, apoptotic activity and gene expression in human colon cancer cells by extracts derived from medicinal herbs, Rhazya stricta and Zingiber officinale and their combination. World J Gastroenterol 2014;20:15275-88. 